\title{
Marginalized Palestinian Youth and Their Media Narratives: Brief Fieldwork Reflections
}

\author{
Nishan Rafi Havandjian ${ }^{{ }^{*}}$, Sanjay Asthana ${ }^{2}$
}

Mass Communication Department, Qatar University, Qatar

College of Mass Communication, Middle Tennessee State University, U.S.A

His voice is faint, but is strangely resilient. As he haltingly tells his story, the tone and his disposition relay a mixture of sadness and unshakable resolve. Meet Miras Al Ez, a camp AIDA resident in Bethlehem. At age 19 he is an experienced photographer who revels in taking videos and snapping photos documenting the daily life of his people.

But Miras' story as a documentarian begins six years ago when he and the other children were instructed by their British trainer how to capture events through their own lens as youngsters in the land of Palestine.

One day as he was playing on his house's balcony, a Israeli soldier right across at an observation post, started shooting at the children with no prior warning. Miras was shot in the belly. His mother took the 13-year-old to the children where a quick surgery saved his life.

There is a certain air of innocence about him as he shows his visitors the scars on his belly. As an adept videographer, immediately decided to tell the world what happened to him through a video he posted and entitled: The Day of Injury.

Miras' case if one of many encountered during our field trip to the West Bank and Israel in January 2013. The mission: With a research grant from the Qatar National Research Fund (QNRF), to study Palestinian youth media and the effect it has on young people as they try to accommodate themselves to the confines of occupation. The following reflections are based on our fieldwork notes and offers perceptive glimpses into the everyday lives of marginalized youth from Palestine.

What is the purpose of Palestinian Youth media? Surely examples of youth generated media around the world abound. Youth using social media sites to formulate and transmit their angst about growing and grownups, their place in society and concerns about the future beholds for them.

A visit to four youth centers, Lajee and Ibda'a in Bethlehem, Pyalara suburban Ramallah and Baladna in Haifa revealed dozens of young Palestinians peering over articles they have just penned, going into the field to shoot videos and rushing to take snapshots of that one event which synthesizes their reality for that particular moment.

It is hard to fathom any youth media approaching the complexity of Palestinian youth media. Here are individuals as young as 12 and as old as mid 20s, using a variety of media to tell an oblivious, complacent world their story, achievements, ambitions and steadfastness under Israeli occupation.

When Miras Al Ez produced his documentary at age 13 about his shooting, he was cognizant that the world media turn a jaundiced eye to such "mundane" run-of-the-mill events. Using his lens was his cry of independence and affirmation of his right to be. It was not a militaristic cry, but one which tells the world in no uncertain terms:
Publication History:

Received: May 18, 2014

Accepted: June 23, 2014

Published: June 25, 2014

I am a Palestinian, still here, despite what happened, and I want the world to know what me and my other young friends endure.

As a case study, the establishment of Camp AIDA, where Lajee Center is located, goes back right at the creation of Israel in 1948. The camp is composed of hundreds of shanty homes where about 5,000 third-generation refugees live. Lajee was established as a communitybased grassroots cultural center offering refugees avenues for exploring and maintaining Palestinian traditions.

A major component of Lajee's activities centers around arts and media projects for children as young as 12 and up to 25 . Projects include photography workshops, digital stories, radio podcasts and a bilingual magazine called Our Voice, which recently ceased publication after its Belgian NGO pulled the plug citing the financial crisis in Europe. Topics in Our Voice dealt with children's rights that include among other things: right of return, right to play, right of young girls, right to freedom of speech, among other topics. Each article was supplemented with appropriate illustrations. The names of the authors and their ages, ranging from 13 to 17 were mentioned at the end of each article.

Over the years, numerous photo workshops at Lajee have been conducted by British photographer and volunteer Rich Wiles. Several of the photo essays have been published and available on Lajee website (www.lajee.org). The photos are evocative accounts of young people's lives from a personal perspective, musings on their dreams and their nightmares under unforgiving occupation. In 2007, Lajee also initiated radio podcast projects set up by an Australian volunteer. The weekly radio podcasts were placed on Lajee website for the world to sample.

Throughout the media output using a wide range of platforms, the young journalists do not blatantly appeal to viewer or reader sympathy. Rather they demonstrate steadfastness (sumud) in the face of flagrant repetitions of atrocities, which brings up the issue of the "other" in Palestinian Youth media.

The "other" here is not an authoritarian government who has no patience for rebellious or troublesome youth, but an occupying force

${ }^{*}$ Corresponding Author: Dr. Nishan Rafi Havandjian, Associate Professor, Mass Communication Department, Qatar University, Qatar; E-mail: nishan@qu.edu.qa

Citation: Havandjian NR, Asthana S (2014) Marginalized Palestinian Youth and Their Media Narratives: Brief Fieldwork Reflections. Int J Journalism Mass Comm 1: 106. doi: http://dx.doi.org/10.15344/2349-2635/2014/106

Copyright: (c) 2014 Havandjian et al. This is an open-access article distributed under the terms of the Creative Commons Attribution License, which permits unrestricted use, distribution, and reproduction in any medium, provided the original author and source are credited. 
which has engaged for the past 65 years to shake the foundations of Palestinian entity and replace it with a tabula rasa where the concepts of national specificity, secure home, and pride in identity are ephemeral memories.

The Lajee project Dreams of Home is based on children's interviews with their grandparents who survived the Al-Nakba. Following the interviews, the children armed with a camera and hand in hand with their grandparents went in search of lost villages. They sauntered from one place to another nudged by granddad's tenacious memories only to discover the village they were seeking was a lost Eldorado, which now reflected the way of life of the usurper occupiers.

\section{Research Grant}

The article is made possible with a National Priorities Research Grant awarded by the Qatar Foundation.

\section{References}

1. Miras, Al Ez, Personal Interview, Aida Refugee Camp, Bethlehem, January 2013

2.Wiles, Rich (2006). Dreams of Home. Ramallah: Lajee 